\title{
Images, emotions, and international politics: the death of Alan Kurdi
}

\author{
Rebecca Adler-Nissen ${ }^{1}$, Katrine Emilie Andersen ${ }^{2}$ and Lene Hansen ${ }^{3 *}$ (D) \\ ${ }^{1}$ University of Copenhagen, ${ }^{2}$ formerly University of Copenhagen and ${ }^{3}$ University of Copenhagen \\ ${ }^{\star}$ Corresponding author. Email: lha@ifs.ku.dk
}

(Received 21 December 2018; revised 5 July 2019; accepted 16 July 2019; first published online 18 October 2019)

\begin{abstract}
How are images, emotions, and international politics connected? This article develops a theoretical framework contributing to visuality and emotions research in International Relations. Correcting the understanding that images cause particular emotional responses, this article claims that emotionally laden responses to images should be seen as performed in foreign policy discourses. We theorise images as objects of interpretation and contestation, and emotions as socially constituted rather than as individual 'inner states'. Emotional bundling - the coupling of different emotions in discourse - helps constitute political subjectivities that both politicise and depoliticise. Through emotional bundling political leaders express their experiences of feelings shared by all humans, and simultaneously articulate themselves in authoritative and gendered subject positions such as 'the father'. We illustrate the value of our framework by analysing the photographs of Alan Kurdi, a three-year-old Syrian-Kurdish boy who drowned in September 2015. 'Kurdi' became an instant global icon of the Syrian refugee crisis. World leaders expressed their personal grief and determination to act, but within a year, policies adopted with direct reference to Kurdi's tragic death changed from an open-door approach to attempts to stop refugees from arriving. A discursive-performative approach opens up new avenues for research on visuality, emotionality, and world politics.
\end{abstract}

Keywords: Alan Kurdi; Discourse; Emotions; Images; Migration; Performativity; Social Media; Visuality

\section{Introduction}

On 2 September 2015, photographs of a small child clad in a red t-shirt and blue pants caught the world's attention. In one photograph, the child was lying on a beach, just where the water met the shore; face down, the body facing in the direction of the ocean. In another photograph, an adult, captured from behind, in a uniform and a green beret, was standing next to the child. In a third photograph, the adult, half-turned towards the camera and identifiable as a man, had picked up the child and started to walk away from the water. The photographs were captured early in the morning by Nilüfer Demir, a Turkish photojournalist, and as the images went viral, the name of the child and the train of events that preceded his death became widely known. The child was a three-year-old boy named Alan Kurdi and the setting a beach near the Turkish tourist town of Bodrum. ${ }^{1}$ Alan Kurdi drowned as his family was trying to reach the Greek island of Kos, twenty kilometres away. Alan's brother Galip and mother Rehana also drowned as their boat capsized, leaving Kurdi's father Abdullah as the family's sole survivor. The Kurdis had fled to Turkey

\footnotetext{
${ }^{1}$ The boy's name was first reported as Aylan. The correct, Kurdish transcription however is Alan.

(C) British International Studies Association 2019. This is an Open Access article, distributed under the terms of the Creative Commons Attribution-NonCommercial-NoDerivatives licence (http://creativecommons.org/licenses/by-nc-nd/4.0/), which permits non-commercial reuse, distribution, and reproduction in any medium, provided the original work is unaltered and is properly cited. The written permission of Cambridge University Press must be obtained for commercial re-use or in order to create a derivative work.
} 
from Kobane, a Syrian town that had come under attack by the Islamic State. Photographs of Alan Kurdi and his brother, smiling and alive, circulating on social and online media, provided a striking visual contrast to the lifeless body on the shore. ${ }^{2}$ The news of how Alan Kurdi's aunt, Tima Kurdi, living in Canada, had pleaded, unsuccessfully, with the Canadian government to help bring some of the family to Canada was seen as evidence that the death of Alan Kurdi could have been avoided.

The public response to the photographs of Alan Kurdi shows the ability of images to invoke emotions. Social media swarmed with testimonies of how the images 'felt like getting punched in the stomach'. ${ }^{3}$ Newspaper editorials, commentary in print and online media, statements by NGOs and the UNHCR echoed the sentiment that this was a heartbreaking, shocking image requiring instant political action. Grief and shame that Europe, and the world more broadly, let children like Kurdi die, were feelings frequently expressed. ${ }^{4}$ Political leaders shared their personal emotional reactions. UK Prime Minister David Cameron, for example, declared that '[a]nyone who saw those pictures overnight could not help but be moved and, as a father, I felt deeply moved by the sight of that young boy on a beach in Turkey.' He added that 'Britain is a moral nation and we will fulfil our moral responsibilities.'

The photographs of Kurdi did not produce new information about the refugee crisis as such: it was well known by September 2015 that people - including children - died trying to cross the Mediterranean Sea. What made the photographs so powerful were their ability to shift the epistemic terrain of the migration discourse from numbers and statistics to an identifiable human with a face, a body, and a life story. ${ }^{6}$ Arguably, the photographs had an 'iconic victim effect', as the photographs of a single individual captured people's attention and generated immediate empathy. ${ }^{7}$ Public support for the refugee cause grew, ${ }^{8}$ and policies and plans were adopted with explicit reference to 'Kurdi'. US President Obama and the newly elected Canadian Prime Minister Justin Trudeau announced plans to resettle Syrian refugees and the EU approved a controversial plan to relocate 120,000 migrants across the continent. German Chancellor Angela Merkel's open-door policy towards refugees, which had just been announced prior to the Kurdi's death, appeared morally and politically validated. ${ }^{9}$

However, as this article will argue, the case of Alan Kurdi shows that the connection between images, emotions, and foreign policies is neither straightforward nor permanent. 'Kurdi' illustrates that an image constituted through an emotional register - of sympathy, pity, and

\footnotetext{
${ }^{2}$ Farida Vis, 'Examining the hundred most shared images of Aylan Kurdi on Twitter', in Farida Vis and Olga Goriunova (eds), The Iconic Image on Social Media: A Rapid Research Response to the Death of Aylan Kurdi (Sheffield, UK: Visual Social Media Lab, 2015), p. 27.

${ }^{3}$ Francesco D'Orazio, 'Journey of an image: From a beach in Bodrum to twenty million screens across the world', in Vis and Goriunova (eds), The Iconic Image on Social Media, p. 11.

${ }^{4}$ Miriam Ticktin, 'A world without innocence', American Ethnologist, 44:4 (2017), p. 577; Gabi Schlag, 'Moving images and the politics of pity: a multilevel approach to the interpretation of images and emotions', in Maéva Clément and Eric Sangar (eds), Researching Emotions in International Relations (Basingstoke: Palgrave Macmillan, 2018), pp. 209-30.

${ }^{5}$ Matt Dathan, 'Aylan Kurdi: David Cameron says he felt "deeply moved" by images of dead Syrian boy but gives no details of plans to take in more refugees', The Independent (3 September 2015), available at: \{http://www.independent.co.uk/news/ uk/politics/aylan-kurdi-david-cameron-says-he-felt-deeply-moved-by-images-of-dead-syrian-boy-but-gives-no- 10484641. html\} accessed 19 December 2018.

${ }^{6}$ Paul Slovic et al., 'Iconic photographs and the ebb and flow of empathic response to humanitarian disasters', Proceedings of the National Academy of Sciences of the United States of America, 114:4 (2017), pp. 640-44; Helen Berents, 'Apprehending the "telegenic dead”: Considering images of dead children in global politics', International Political Sociology, 13:2 (2019), p. 11.

${ }^{7}$ Slovic et al., 'Iconic photographs', p. 641.

${ }^{8}$ Ibid.; Laura G. E. Smith et al., 'After Aylan Kurdi: How tweeting about death, threat, and harm predict increased expressions of solidarity with refugees over time', Psychological Science, 29:4 (2018), pp. 623-34; Lin Prøitz, 'Visual social media and affectivity: the impact of the image of Alan Kurdi and young people's response to the refugee crisis in Oslo and Sheffield', Information, Communication and Society, 21:4 (2018), pp. 548-63.

${ }^{9}$ Adina Maricut, 'Different narratives, one area without internal frontiers: why EU institutions cannot agree on the refugee crisis', National Identities, 19:2 (2017), pp. 161-77; Roland Bleiker, Visual Global Politics (London: Routledge, 2018 ), p. 19.
} 
compassion - can be connected to markedly different policies. ${ }^{10}$ 'Alan Kurdi' remains a powerful rhetorical reference, but within a year, policies adopted with direct reference to his tragic death changed from an open-door approach to an attempt to stop refugees ever arriving in Europe. Kurdi, most strikingly, became a justification for a controversial agreement between the EU and Turkey in March 2016, an agreement that effectively closed the migration route from Turkey to the Greek islands.

The empirical aim of this article is to provide an analysis of how the photographs of Kurdi became constituted, in particular how emotions and political subjectivities were articulated to legitimise a range of policy responses. The theoretical aim is to develop a conceptual framework to study how images, emotions, and foreign policies are connected in cases such as that of Alan Kurdi. In doing so, we seek to contribute to two related research agendas in International Relations (IR): one on images and visuality and one on emotions. Both strands of scholarship argue that images have the capacity to invoke emotions, but thus far there has been little work exploring this in more detail. ${ }^{11}$ Our theorisation starts from the premise that there is a need for studying emotions and emotional responses to images as constituted through discourse. That is, our article contributes to IR scholarship on emotions as collective, intersubjectively constituted phenomena. ${ }^{12}$ Specifically, we introduce the concept of emotional bundling to capture how images can be constituted as invoking a range of emotions. Sympathy, grief, pity, compassion, and shame have been used to describe the emotional responses when seeing the photographs of Kurdi. There are, however, important differences in how these emotions - for example pity and compassion ${ }^{13}$ - constitute those in need of help and those who could or should provide it. Emotional bundling may sideline such differences by not making them explicit and thus enable many different responses. This increases the support for an emotional-political call for action as multiple actors and audiences can recognise their specific emotional response in the bundling process. Emotional bundling may at the same time produce vagueness at the level of policy formulation: the multiple emotional responses that an image is said to invoke may support the call for 'something to be done', but leave the specificity of the 'doing' undecided.

We also begin with the premise that all images are polysemic, that is, there is no universal or essential message that an image evokes. While some visual motifs have a history of being able to invoke particular emotions, even images with an emotional historicity - such as that of the young child inviting pity or compassion ${ }^{14}$ - do not automatically cause specific policies to be adopted. Images with an 'emotional potentiality' have to be constituted as in need of collective and political action. ${ }^{15}$ We suggest that the emotional politics of images is best captured as performative where the emotional significance of images and their message are largely constituted discursively through the policies they are said to require or justify. Moreover, because emotional discourse revolves around a

\footnotetext{
${ }^{10}$ We use 'Kurdi' to refer to the iconic photographs and Kurdi when referring to accounts and news stories about Alan Kurdi and his family.

${ }^{11}$ Schlag, 'Moving images and the politics of pity' is a partial exception.

${ }^{12}$ Emma Hutchison, Affective Communities in World Politics (Cambridge: Cambridge University Press, 2016); Karin M. Fierke, Political Self-Sacrifice: Agency, Body and Emotion in International Relations (Cambridge: Cambridge University Press, 2013). We contribute in particular to the research agenda on discourse and emotion laid out in 'The Forum: Discourse and emotions in International Relations', International Studies Review, 19:3 (2017), pp. 481-508. As Simon Koschut holds in his introduction 'there has been strikingly little elaboration of appropriate methods and criteria for studying emotion discourse'. Simon Koschut, 'Introduction to discourse and emotions in International Relations', International Studies Review, 19:3 (2017), p. 482. We speak to this lacuna in research on emotions while incorporating the visual dimension not addressed by this Forum.

${ }^{13}$ Roland Bleiker and Amy Kay, 'Representing HIV/AIDS in Africa: Pluralist photography and local empowerment', International Studies Quarterly, 51:1 (2007), pp. 139-63.

${ }^{14}$ Ticktin, 'A world without innocence', p. 577; Erica Burman, 'Innocents abroad: Western fantasies of childhood and the iconography of emergencies', Disasters, 18:3 (1994); Kate Manzo, 'Imagining humanitarianism: NGO identity and the iconography of childhood', Antipode, 40:4 (2008), pp. 632-57; and Berents, 'Apprehending the "telegenic dead”'.

${ }^{15}$ Roland Barthes, Camera Lucida: Reflections on Photography (New York: Hill and Wang, 1981).
} 
felt, often individual experience or personal reaction, it is a key site for the performance of political subjectivity. That is, we theorise the discourse of emotional responses to images as always being both discourses about the images and those who speak about them. These political subjectivities are performed, and when actors with power and authority do so, they become significant for policymaking.

The article is divided into two parts. The first part presents our theoretical framework, conceptualising and connecting images, emotions, and foreign policy. The second part provides an illustration of how our theoretical framework can be applied to the case of 'Kurdi'. We conclude by outlining our theoretical argument and how a research agenda on emotions, images, and international politics might move forward.

\section{The emotional impact of images: a performative-discursive approach}

It is often held that images have a particular capacity to invoke emotions. ${ }^{16}$ Scholars interested in emotions and international politics have drawn attention to the capacity of images to connect individual emotions with larger, collective feelings of community. ${ }^{17}$ Todd Hall, for example, has argued that the response of Russia and China to the US intervention into Afghanistan after $9 / 11$ is impossible to account for without acknowledging the role of sympathy engendered by the images that were 'viewed in real time across the globe. ${ }^{18}$ Emma Hutchison holds that visual representations of the 2004 tsunamis in Southeast Asia suggested to Western audiences that they should feel emotionally compelled to act in support of the victims. ${ }^{19}$ Roland Bleiker and Michael C. Williams have theorised how visual representations mobilise populations through emotive-aesthetic forms of communication. ${ }^{20}$ Approaching images and emotions from the perspective of securitisation theory, the ability of visual representations to securitise and be securitised has been at the centre of studies of, for example, the Danish Muhammad Cartoon Crisis. ${ }^{21}$

Although emotions and images have been connected by prior work, it has not been at the centre of theorisation or analysis. As evidenced by Hutchison's recent account of emotions in IR scholarship, this is a vast and fast-growing field of research operating across different levels of analysis and with different epistemological and methodological commitments. ${ }^{22}$ Consequently, there are numerous ways in which the relationship between emotions and images could be studied. One approach is to conduct experimental research demonstrating the effect of images, for example, on the willingness to donate money for victims of famine or to support wars abroad. ${ }^{23}$ Bleiker et al., for instance, draw on psychological experiments on the 'identifiable victim effect' in their analysis of photographic images of boat migrants in Australian news media. ${ }^{24}$ Images of small numbers of

\footnotetext{
${ }^{16}$ Roland Bleiker, 'Pluralist methods for visual global politics', Millennium: Journal of International Studies, 43:3 (2015), p. 876; Lene Hansen, 'Theorizing the image for security studies: Visual securitization and the Muhammad Cartoon Crisis', European Journal of International Relations, 17:1 (2011), pp. 51-74.

${ }^{17}$ Roland Bleiker and Emma Hutchison, 'Fear no more: Emotions and world politics', Review of International Studies, 34 (2008), pp. 115-35; Todd Hall and Andrew Ross, 'Affective politics after 9/11', International Organization, 69:4 (2015), p. 857; Hutchison, Affective Communities in World Politics.

${ }^{18}$ Todd Hall, 'Sympathetic states: Explaining the Russian and Chinese responses to September 11', Political Science Quarterly, 127:3 (2012), p. 371; see also Bleiker and Hutchison, 'Fear no more', p. 131.

${ }^{19}$ Hutchison, Affective Communities in World Politics, p. 209.

${ }^{20}$ Roland Bleiker, Aesthetics and World Politics (New York: Palgrave Macmillan, 2009); Michael C. Williams, 'Words, images, enemies: Securitization and international politics', International Studies Quarterly, 47:4 (2003), pp. 511-31; Michael C. Williams, 'International Relations in the age of the image', International Studies Quarterly, 62:4 (2018), pp. 880-91.

${ }^{21}$ Hansen, 'Theorizing the image for security studies'.

${ }^{22}$ Hutchison, Affective Communities in World Politics.

${ }^{23}$ Roland Bleiker et al., 'The visual dehumanisation of refugees', Australian Journal of Political Science, 48:4 (2013), pp. 398416; Scott Sigmund Gartner, 'On behalf of a grateful nation: Conventionalized images of loss and individual opinion change in war', International Studies Quarterly, 55:2 (2011), pp. 545-61; Scott Sigmund Gartner and Christopher F. Gelpi, 'The affect and effect of images of war on individual opinion and emotions', International Interactions, 42:1 (2016), pp. 172-88.

${ }^{24}$ Bleiker et al., 'The visual dehumanisation of refugees'.
} 
migrants with identifiable faces, they argue, invoke a politics of pity; images of large numbers of migrants with indistinguishable features invoke, in contrast, a politics of fear. ${ }^{25}$

A second approach advanced by Andrew Ross is to understand emotions as complex, social phenomena with unconscious, physiological, and neurological components, focusing on how emotions are transmitted across individuals and groups in 'circulations of affect', ${ }^{26}$ complicating the idea that emotions have direct and causal effect. Recently, Constance Duncombe has adopted a similar approach seeing emotions as complex phenomena and exploring how Twitter both represents and provokes emotions. ${ }^{27}$

A third approach, and the one we will develop here, is to situate emotions at the level of public collective representations. Neta C. Crawford defined emotions as 'the inner states that individuals describe to others as feelings, and those feelings may be associated with biological, cognitive, and behavioral states and changes'. ${ }^{28}$ When individuals describe their feelings to others, they constitute them through language. In this article, we theorise emotions as articulated in discourse, not as psychological reactions situated within the individual or groups of individuals. This approach is particularly applicable to those categories of images that are the subject of public debate.

Our theoretical framework revolves around two assumptions about performativity. The first assumption concerns the relationship between images and foreign policies. Drawing on poststructuralist work in IR on the performative relationship between identity and foreign policy, this entails an analytical focus 'on the discursive construction of identity as both constitutive of and a product of foreign policy'. ${ }^{29}$ Adapting this to the particular study of visual representations, it implies focusing on how images are constituted in policy discourse. An image might be said to speak univocally to everyone's feelings thus requiring a particular foreign policy to be adopted. Yet we treat such statements as discursive performative acts that constitute the image as such, rather than statements that demonstrate the inevitability of one particular interpretation of the image. As Roland Barthes famously put it, images are polysemic, that is, they are always open to multiple interpretations. ${ }^{30}$ There is, held Barthes, a difference between a photograph's denoted message (what is concretely visible) and its connoted message (the codes that a particular society employ to read it). Connotative messages relate to the production and reception of an image, and to 'the stock of signs' that are familiar to a given public. ${ }^{31}$ One might try to describe the denoted message of a photograph as objectively as possible, but it is impossible not to bring some connotation into this description. As an image becomes publicly known, through speech and writing, it is constituted through a particular set of codes that have a social and contextual history. Even images of children, and motifs such as Madonna and Child, have a particular historicity. ${ }^{32}$ For an image to become socially significant some interpretation needs to be established, the image needs to be 'anchored', and the most prominent form of anchoring for Barthes was that of the linguistic message. ${ }^{33}$ Ontologically and epistemologically, there is a co-constitutive, performative relationship between the image and the policy it is held to necessitate. In other words, the 'discursive-visual causality' is constituted through

\footnotetext{
${ }^{25}$ For an overview of how emotions relate to level-of-analysis debates in IR, see Jonathan Mercer, 'Human nature and the first image: Emotion in international politics', Journal of International Relations and Development, 9:3 (2016), pp. $288-303$.

${ }^{26}$ Andrew A. G. Ross, Mixed Emotions (Chicago: University of Chicago Press, 2014), p. 20.

${ }^{27}$ Constance Duncombe, 'The politics of Twitter: Emotions and the power of social media', International Political Sociology, Online First (2019), pp. 1-21.

${ }^{28}$ Neta C. Crawford, 'The passion of world politics: Propositions on emotion and emotional relationships', International Security, 24:4 (2000), p. 125.

${ }^{29}$ Lene Hansen, Security as Practice: Discourse Analysis and the Bosnian War (London: Routledge, 2006), p. 23.

${ }^{30}$ Roland Barthes, Image, Music, Text (Glasgow: Fontana, 1977), p. 39.

${ }^{31}$ Ibid., pp. 17-19.

${ }^{32}$ Ticktin, 'A world without innocence'; Marita Sturken and Lisa Cartwright, Practices of Looking: An Introduction to Visual Culture (2 ${ }^{\text {nd }}$ edn, New York: Oxford University Press, 2009), pp. 39-46.

${ }^{33}$ Barthes, Image, Music, Text, p. 39.
} 
policy discourse, ${ }^{34}$ rather than being a 'direct' causal relationship where certain images are bound to cause particular policies to be adopted.

The second assumption about performativity concerns the relationship between emotions and foreign policies. Emotions are performed discursively as if produced by particular images. ${ }^{35}$ For example, when US President Obama describes the iconic photograph of the dying young Iranian protester Neda Agha-Soltan as 'heartbreaking', it is a public articulation that constitutes this image with a particular emotional status. ${ }^{36}$ Such public emotional responses to images are not simply accounts of a personal, psychological experience (in fact they need not even be experienced or felt), they are performative and have effects in terms of constituting political subjectivities and appropriate policy responses. Put differently, whether someone personally experiences the emotions that they discursively perform is beyond the theoretical and empirical scope of the analysis. ${ }^{37}$

When emotional responses to images are performed in foreign policy discourses they constitute political subjectivities. This is because the articulation of emotion always also constitutes a subject speaking as someone who feels. Thus, images can be said to evoke emotions not only by documenting, for example, violence or atrocities, but through an articulation of the personal experience of viewing the images. Images can become iconic - and emotionally responded to not only due to 'the realism ascribed to the photo or its relationship to a single set of moral precepts', but if a structure of moral public response is constructed, 'adapted to the deep problems in the public culture at the time'. ${ }^{38}$ Photographic images in particular allow the viewer to be brought back to the same time and place as when the image was captured. The image does not 'strictly speaking, postdate the event, but becomes crucial to its production, its legibility, its illegibility, and its very status as reality. ${ }^{39}$ To articulate oneself as feeling provides the possibility for humanising oneself, for example as a leading politician who feels like 'a father'. Emotional discourse often articulates a bond, what Hutchison calls an affective community, among humans who feel the same. ${ }^{40}$ However, the constitution of a 'humanized political subjectivity' might also depoliticise an issue if the emotional responses are constituted as a private, non-political experience, rather than as a public one. It is important therefore to analyse how the constitution of political subjectivity is connected to the need for political action and responsibility.

Our epistemological and methodological strategy for studying emotional responses in discourse is to start from how emotional responses are constituted through claims to being emotionally affected through the invocation of particular feelings of shame, fear, or anger, for example. ${ }^{41}$ Our approach implies that what is considered an emotional response might itself be historically and culturally situated. ${ }^{42}$ There might also be some ambiguity as to whether a felt response is constituted as an emotion or not. A 'shock', for example, might connote emotion in some situations, but not in others.

\footnotetext{
${ }^{34}$ Hansen, Security as Practice, p. 26; Bleiker, 'Pluralist methods for visual global politics', p. 885.

${ }^{35}$ Emma Hutchison and Roland Bleiker, 'Emotions, discourse and power in world politics', International Studies Review, 19:3 (2017), pp. 501-05.

36، 100 photos: the death of Neda', Time Magazine (2009), available at: $\{$ http://100photos.time.com/photos/death-of-neda $\}$ accessed 19 December 2018.

${ }^{37}$ It might become analytically interesting however if questions of sincerity are raised within a political debate. Fierke, Political Self-Sacrifice.

${ }^{38}$ Robert Hariman and John L. Lucaites, No Caption Needed: Iconic Photographs, Public Culture, and Liberal Democracy (Chicago: University of Chicago Press, 2007), p. 175.

${ }^{39}$ Judith Butler, 'Torture and the ethics of photography', Environment and Planning D: Society and Space, 25:6 (2007), pp. 951-66.

${ }^{40}$ Hutchison, Affective Communities in World Politics.

${ }^{41}$ On methods and emotions, see also Roland Bleiker and Emma Hutchison, 'Methods and methodologies for the study of emotions in world politics', in Clément and Sangar (eds), Researching Emotions in International Relations, pp. 325-42.; Schlag, 'Moving images and the politics of pity'.

${ }^{42}$ Koschut, 'Introduction to discourse and emotions', p. 483.
} 
Multiple emotional responses might also be found in what we call emotional bundling where emotions - such as pity and compassion as well as grief and shame - are articulated as similar emotional responses. This is typically the case when images are studied at a general level of discourse. Yet, such emotions might arguably invoke quite different subjectivities. For example, as Bleiker and Kay hold in their study of photography and HIV/AIDS, there are important differences in whether those afflicted are seen as warranting pity or compassion. ${ }^{43}$ Drawing on Arendt, Bleiker and Kay define pity as a 'more abstract and generalized form of politics', whereas compassion is a sentiment 'directed toward particular individuals'. ${ }^{44}$ The limitation of pity, when evoked through generic images of HIV/AIDS suffering in Africa, is that those suffering are seen as passive and without historical, political, and socioeconomic context. ${ }^{45}$ Our notion of emotional bundling is similar to Andrew Ross's argument that emotions are not bounded, discrete things, but are always in the making. However, our ontological and epistemological approaches differ in that we study emotions as constituted in discourse at the collective level, whereas Ross includes unconscious and bodily experiences of emotions. ${ }^{46}$

Our methodological suggestion is to analyse how emotional bundling is produced, and what the implications are for political responsibility and action. We expect that emotional bundling can reinforce the demand for - or legitimacy of - particular foreign policies. For example, a political actor arguing that a humanitarian intervention is required after viewing images of civilian victims might appeal to audiences who find those images moving, but in different emotional registers. Emotional bundling might also make the constitution of political responsibility more vague or more ambiguous. It might become harder to establish a link from emotional responses to foreign policy if a range of emotions are invoked at the same time. Emotional bundling might in such cases diffuse the pressure on foreign policies to be enacted.

\section{The emotional politics of images: the case of Alan Kurdi}

We now turn to using our theoretical framework to analyse the emotionally charged responses to the photographs of Alan Kurdi. Our analysis is organised into four components, enabling us to explore in more detail the theoretical concepts and arguments laid out above. The first component focuses on the anchoring of the polysemic images of 'Kurdi' through discourse and the established iconography of the child. We show how an emotional bundling of responses ranging from sadness and pity to compassion and anger takes place from the first circulation on social media. The second component identifies and analyses those discourses that contested the reigning representation of 'Kurdi'. The third component traces how the emotional discourse adopted by Western politicians revolved around a performative constitution of the subjectivities of 'parent' and 'father'. The fourth component examines the relationship between 'Kurdi' and Western refugee policies adopted in the aftermath of the photographs' circulation. We draw on the concept of performativity in two ways: we show how claims about the ability of 'Kurdi' to change Western policies are central to the iconic status of the images and we demonstrate how 'Kurdi' is used to legitimise a policy that opens the borders to Europe for refugees, but also one that closes them.

\section{An instant global icon: Emotional bundling and the subject of 'the child'}

The photographs of Kurdi became instant global icons, that is, images that circulate immediately to a worldwide audience generating an emotional response'. ${ }^{47}$ The photographs met with an

\footnotetext{
${ }^{43}$ Bleiker and Kay, 'Representing HIV/AIDS in Africa'.

${ }^{44}$ Ibid., p. 150.

${ }^{45}$ Ibid., p. 149.

${ }^{46}$ Ross, Mixed Emotions, p. 1.

${ }^{47}$ Lene Hansen, 'How images make world politics: International icons and the case of Abu Ghraib', Review of International Relations, 41:2 (2016), pp. 271-2; see also David Campbell, 'Atrocity, memory, photography: Imaging the concentration
} 
immediate emotional response when they started circulating on social media. The figure of the child as innocent and vulnerable is so established, at least in contemporary Western culture, that it might seem self-evident that a photograph of a small dead child would be met by an outpour of sadness, sorrow, compassion, pity, and grief. ${ }^{48}$ Theoretically, it is therefore important to stress that although this tradition endowed the motif of Alan Kurdi with an emotional potentiality, it was nevertheless an emotional potentiality that had to be made explicit and brought out.

That the images of 'Kurdi' should be theorised as having an emotional potentiality rather than inevitability is further supported empirically by the fact that these were not the first images of dead children featured in mainstream news media, though that was a claim sometimes made. ${ }^{49}$ In July 2014, for example, The New York Times published a photograph of a child killed in an airstrike in Gaza, in a pose quite similar to that of Alan Kurdi. ${ }^{50}$ Theoretically, drawing on Barthes's distinction between a photograph's denotative and connotative messages, the photographs of Kurdi are actually rather polysemic at the denotative level. The photograph of Kurdi alone on the beach, in particular, provides no narrative about what brought him there. It could have been an accident unrelated to the Syrian civil war, or Mediterranean migration routes, or European policies. The first element in the constitution of 'Kurdi' is thus an articulation of these as images that are emotional. As news media starts to write about the display of emotions on social media, the constitution of 'Kurdi' as a deeply moving image gains hold. To take an example, The Guardian editorial on 4 September 2015 noted that 'One photograph has turned something we all knew was happening, but somewhere little-known and far away, into a wrenching tragedy that demands immediate action.' It becomes established as a social fact that it would be impossible not to respond to 'Kurdi' in an emotionally charged way.

The constitution of 'Kurdi' as a subject for whom 'we' should harbour feelings takes place from the very first tweeting of the photographs by Peter Bouckaert, Emergency Director at Human Rights Watch. ${ }^{51}$ Bouckaert creates several tweets and though he does not explicitly use the word 'emotion', he speaks to his audience as if they were actual or potential parents: 'Just pause 4 moment \& imagine this was your child, drowned trying 2 flee \#Syria war 4 safety of \#EU. \#solidarity'. ${ }^{52}$ The constitution of 'Kurdi' as 'your child' involves what Althusser defined as an interpellation: a subject is addressed in a way that, if accepted, involves a particular subject position. ${ }^{53}$ The concept of interpellation underscores that Bouckaert's tweet provides an instruction: you should imagine this child as yours. As work on the constitution of the figure of the child has laid out, to describe somebody as a child is not only to differentiate some bodies from others based on age, but to invoke a particular discourse and particular identities. At least within contemporary Western society, 'children are seen as in need of nurturance and protection, in need of

camps of Bosnia - the case of ITN versus Living Marxism, Part 1', Journal of Human Rights, 1:1 (2002), for an analysis of the photograph of emaciated prisoner Fikret Alic from August 1992 as 'an instant icon of the Bosnian war'.

${ }^{48}$ Burman, 'Innocents abroad'; Manzo, 'Imagining humanitarianism'; Berents, 'Apprehending the "telegenic dead”'; Susan Moeller, 'A hierarchy of innocence: the media's use of children in the telling of international news', Harvard International Journal of Press/Politics, 7:1 (2002), pp. 36-56; Ticktin, 'A world without innocence'.

${ }^{49}$ Sushama Kasbekar, 'Photojournalism: Journalistic reality and necessity', IRA International Journal of Education and Multidisciplinary Studies, 3:1 (2016), p. 98; Berents, 'Apprehending the “telegenic dead"', p. 2.

${ }^{50}$ Anne Barnard, 'Boys drawn to Gaza beach, and into center of Mideast strife', The New York Times (16 July 2014), available at: $\{$ https://www.nytimes.com/2014/07/17/world/middleeast/gaza-strip-beach-explosion-kills-children.html\} accessed 18 December 2018. For an analysis of the photographs, see Berents, 'Apprehending the "telegenic dead"'.

${ }^{51}$ The boat capsized the night between 1 and 2 September, and the pictures were sent and emailed to Bouckaert the same morning. On Twitter and international politics, see Constance Duncombe, 'Twitter and transformative diplomacy: Social media and Iran-US relations', International Affairs, 93:3 (2017), pp. 545-62.

${ }^{52}$ Peter Bouckaert, Twitter post (4:29 AM, 2 September 2015), available at: \{https://twitter.com/bouckap/status/ 639037338362978304/photo/1\} accessed 18 December 2018.

${ }^{53}$ For an introduction to the work of Althusser, see Ernesto Laclau and Chantal Mouffe, Hegemony and Socialist Strategy (London: Verso, 1985); for an application of the concept of interpellation in IR, see Jutta Weldes, Constructing National Interests: The United States and the Cuban Missile Crisis (Minnesota: University of Minnesota Press: 1999), pp. 103-07. 
supportive family relationships and (especially when those are considered inadequate) caring institutions'. ${ }^{54}$ Children as innocent and worthy of sympathy is a visual and textual figure employed, for example, by NGO's campaigning for donations. ${ }^{55}$ As scholarship on children has shown, 'the child' is a modern construction that emerged within Northern industrialised societies in the nineteenth century. ${ }^{56}$ It is a constitution with a link to colonial ideology as employed within missionary discourse and practices, and more recently, development theory and aid. ${ }^{57}$ As Kate Manzo explains, the constitution of the innocent, dependent child involves as a double colonial paternalism: of the South as childlike and thus in need of Northern assistance/intervention and of the South as unable to care adequately for 'its' children. ${ }^{58}$

The child has a complex genealogy as a 'moral referent' that can be constituted in multiple ways. ${ }^{59}$ 'Your child' in Bouckaert's tweet can imply universality, where all adults are interpellated to respond emotionally and push for political action. But it can also invoke a more selective Western discourse that constitutes children in the global South as in need of Northern rescue. Set within those discourses, there is an ambiguity to 'Kurdi'. As Berents points out, the child in the photograph 'looks like it could be any child', yet as Bouckaert's first tweets underlines, this is a child who has fled from the Syrian war, that is, he is constituted as 'one of the thousands of bodies from the Global South trying to reach Europe' ${ }^{60}$ The constitution of 'Kurdi' as 'your child' also relates to the Northern tradition of representing 'child victims' 'as an individual, decontextualized, without parents or guardians in the image', a representation supported by the lack of context in the iconic photograph of Kurdi lying alone on the shore. ${ }^{61}$ But the narrative of Alan Kurdi and his family, photographs of Alan and his brother, and the widely reported emotional responses of his father, Abdullah, and his aunt Tima crying in front of television cameras on her front lawn in British Columbia, Canada, go some way in terms of anchoring the decontextualised scene.

Bouckaert's interpellation to experience Alan Kurdi as 'your child' was coupled with a call for 'solidarity' and bringing an end to the political 'inaction' of the EU. As the photographs went viral on social media - more than twenty million people saw them on Twitter in the first 12 hours after they first appeared ${ }^{62}$ - the constitution of 'Kurdi' as an innocent victim worthy of an emotional response and a change in refugee and migration policies gains hold. ${ }^{63}$ Multiple actors are held responsible, including 'Europe', 'the international community', the EU, and Canada. Many comments on Chinese social media, including the microblogging platform Weibo, held the US accountable for Kurdi's death on the grounds that the US supported the uprising in Syria in

\footnotetext{
${ }^{54}$ Burman, 'Innocents abroad', p. 239.

${ }^{55}$ Manzo, 'Imagining humanitarianism'; Berents, 'Apprehending the "telegenic dead”, p. 4.

${ }^{56}$ Burman, 'Innocents abroad'.

${ }^{57}$ Manzo, 'Imagining humanitarianism', p. 636.

${ }^{58}$ Ibid., p. 636.

${ }^{59}$ Moeller, 'A hierarchy of innocence', p. 38.

${ }^{60}$ Berents, 'Apprehending the "telegenic dead"', p. 12.

${ }^{61}$ Ibid., p. 4.

${ }^{62}$ D’Orazio, 'Journey of an image', p. 12.

${ }^{63}$ For a more detailed account of how the images were shared on social media, see Vis and Goriunova (eds), The Iconic Image on Social Media; Mette Mortensen, 'Constructing, confirming, and contesting icons: the Alan Kurdi imagery appropriated by \#humanitywashedashore, Ai Weiwei, and Charlie Hebdo', Media, Culture and Society, 39:8 (2017); Thomas Olesen, 'Memetic protest and the dramatic diffusion of Alan Kurdi', Media, Culture and Society, 40:5 (2018), pp. 656-72; and Meenakshi Gigi Durham, 'Resignifying Alan Kurdi: News photographs, memes, and the ethics of embodied vulnerability', Critical Studies in Media Communication, 35:3 (2018), pp. 240-58. Unfortunately, we do not have the space to go into a further theorisation of the relationship between social media, images, and emotions in this article. As one of our reviewers pointed out, social media produce global inequalities in terms of what gets circulated and how that is represented. We hope to be able to address this in detail in future work. See Helen Berents, 'Hashtagging girlhood: \#IAmMalala, \#BringBackOurGirls and gendering representations of global politics', International Feminist Journal of Politics, 18:4 (2016), pp. 513-27 for an analysis of social media campaigns and global inequality.
} 
2011. ${ }^{64}$ The attribution of responsibility was also voiced by heads of state within and beyond Europe and the Middle East. Brazilian president Dilma Rousseff stated that European countries were responsible for the death of Kurdi: 'He died because he was abandoned, because countries created barriers for the entrance of that child.' In contrast to European states, Brazil was a welcoming and multi-ethnic country, Rousseff said. ${ }^{65}$

The articulation of emotions took place through statements about what seeing 'Kurdi' evoked, but also through the creation of new images. After 48 hours, the most frequently circulated image on Twitter had changed from the original photographs to user-remediated versions, in particular of the motif of Alan Kurdi alone on the beach. ${ }^{66}$ The global scale of the remediations of the photographs is also covered in mainstream news stories, adding to the icon's circulation. ${ }^{67}$ Comparisons with previous photographic icons were also frequent and 'Kurdi's' iconic status was reinforced through performative statements that this really was an iconic photograph.

The remediations of iconic photographs are significant in several ways. ${ }^{68}$ They provide an additional way in which the iconic motif is circulated potentially to new audiences and they turn receivers into producers of images. Remediations are utterances that express emotions. As they circulate they might engender emotional responses, too. The speed with which the remediations of 'Kurdi' appear is striking as is the number and range of images. Remediations centre on the theme of the innocence of 'Kurdi'. Illustrators, graphic designers, editorial cartoonists, artists and 'ordinary citizens' with no specific credentials create collages and drawings that situate Kurdi into new settings. Others employ the bodily posture of Kurdi and the setting of the beach, but substitute Kurdi for other figures such as adult men in business suits. Some re-enact the photograph and circulate pictures of their performances. Murals, graffiti, and street art are documented and circulated beyond their site-specific location (Figure 1).

As one website collecting remediations of 'Kurdi' put it, the photographs inspired 'a powerful emotional response from artists around the world. These touching responses range from grief to rage, and regardless of where you stand on the Syrian refugee crisis and Europe's response, one thing is certain - children like Aylan and Ghalib should not be dying like this. ${ }^{69}$ Some mediations criticise the international community, for example by repositioning Kurdi in the middle of the assembly of the Arab League, or by adding blue background and the yellow stars of the EU or by incorporating words such as 'SHAME, SHAME, SHAME' to the motif. ${ }^{70}$ The political message is less overt in mediations that underscore Kurdi's status as a small child by depicting him devoid

\footnotetext{
${ }^{64}$ Bethany Allen-Ebrahimian, 'Chinese web users grieve for Syrian toddler - and blame America', Foreign Policy (4 September 2015), available at: \{https://foreignpolicy.com/2015/09/04/china-syria-migrant-crisis-photo-aylan-kurdi-democracy/\} accessed 18 December 2018.

${ }^{65}$ Stephen Eisenhammer, 'Brazil president criticizes Europe over refugee crisis', Reuters (5 September 2015), available at: \{https://www.reuters.com/article/us-europe-migrants-brazil-idUSKCN0R42IE20150904\} accessed 18 December 2018.

${ }^{66}$ D’Orazio, 'Journey of an image', p. 18.

${ }^{67}$ See, for example, Associated Press, '21 cartoons about dead child on beach who is haunting and frustrating the world', The Malta Independent (4 September 2015), available at: \{http://www.independent.com.mt/articles/2015-09-04/world-news/ 21-cartoons-about-dead-child-on-beach-who-is-haunting-and-frustrating-the-world-6736141577\}; 'Artists create heartbreaking cartoons following drowned Syrian toddlers' deaths', AsiaOne (5 September 2015), available at: \{http://www.asiaone.com/ world/artists-create-heartbreaking-cartoons-following-drowned-syrian-toddlers-deaths\}; Rédaction du HuffPost avec AFP, 'Aylan Kurdi: les dessinateurs s'emparent de la photo du petit Syrien', The Huffington Post France (5 October 2015), available at: \{https://www.huffingtonpost.fr/2015/09/03/aylan-kurdi-dessinateurs-syrien_n_8082480.html\}; Fanny Hubert, 'Cartoonists of the world commemorate the tragic death of Aylan Kurdi', Konbini (4 September 2015), available at: http://www.konbini. com/us/inspiration/cartoonists-world-commemorate-tragic-death-aylan-kurdi/\} accessed 18 December 2018.

${ }^{68}$ Hariman and Lucaites, No Caption Needed.

${ }^{69}$ Julija Nejè, 'Artists around the world respond to tragic death of 3-year-old Syrian refugee', Bored Panda (n.d.), available at: $\quad\{$ http://www.boredpanda.com/syrian-boy-drowned-mediterranean-tragedy-artists-respond-aylan-kurdi/\} accessed 18 December 2018, emphasis added.

${ }^{70}$ Mortensen, 'Constructing, confirming, and contesting icons', pp. 1148, 1151.
} 


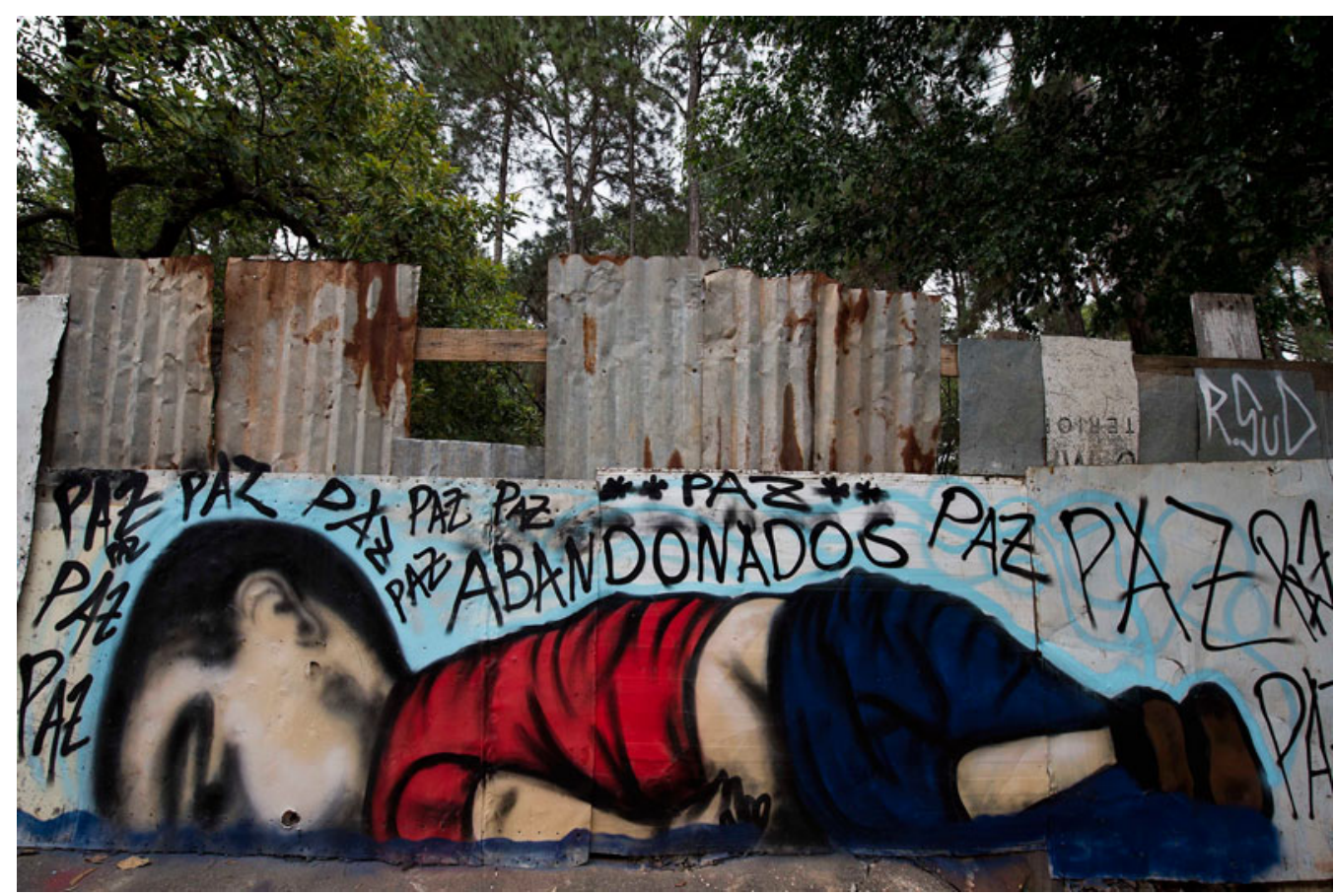

Figure 1. A mural in Sorocaba, ninety kilometres from Sao Paolo, Brazil, 6 September 2015. ( ) Nelson Almeida / AFP / Ritzau Scanpix.

of context, in the form of an angle or sleeping in a child's bedroom. ${ }^{71}$ It is worth noting though that those less overtly political mediations were in some cases applied to make explicitly criticalpolitical statements. For example, the global civic society organisation Avaaz used the frequently circulated motif of Alan Kurdi as an angel in a Wall of Welcome located right in front of the European Union headquarters in Brussels (Figure 2). Thus while these remediations of 'Kurdi' can be separated into different analytical categories, for example those that decontextualise or recontextualise the figure of Alan Kurdi when the photographs were circulated, seen and (re)used we see a process of emotional bundling as mediations are connected across those analytical categories. ${ }^{72}$

The responses to 'Kurdi' provide a striking example of emotional bundling as feelings of sadness, sorrow, pity, grief, compassion, sympathy, and anger are articulated together. ${ }^{73}$ As argued above, pity and compassion, for example, are feelings with potential distinctions and nuances in how they constitute the relationship between those who feel and those who are the subject of those feelings. What is striking in the case of 'Kurdi' is that those differences receive little, if any, explicit mention. ${ }^{74}$ The response to 'Kurdi' was thus able to accommodate a range of different emotional performances through an emotional bundling.

\footnotetext{
${ }^{71}$ Ibid., pp. 1150, 1153; Lilie Chouliaraki and Tijana Stolic, 'Rethinking media responsibility in the refugee "crisis": a visual typology of European news', Media, Culture and Society, 39:8 (2017), p. 1171; on the appropriation of the Kurdi photographs, see also Olesen, 'Memetic protest and the dramatic diffusion of Alan Kurdi', pp. 656-72; and Durham, 'Resignifying Alan Kurdi'.

${ }^{72}$ Mortensen, 'Constructing, confirming, and contesting icons'; see also Olesen, 'Memetic protest and the dramatic diffusion of Alan Kurdi'.

${ }^{73}$ Schlag, 'Moving images and the politics of pity'; Bleiker, Visual Global Politics, p. 19.

${ }^{74}$ Durham, in 'Resignifying Alan Kurdi', discusses the differences between more political and more 'sentimental' appropriations of 'Kurdi'.
} 


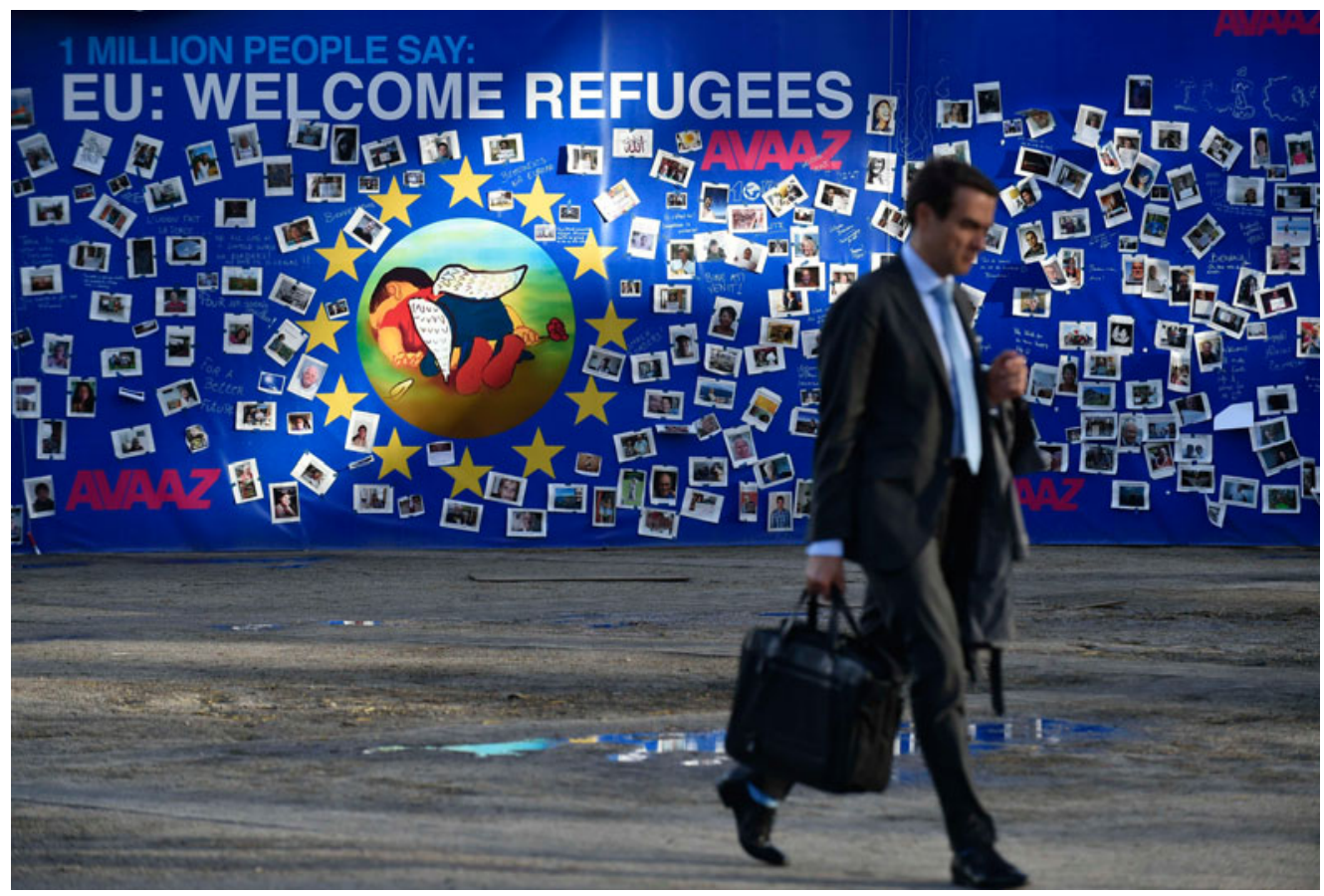

Figure 2. The Wall of Welcome at the Schuman Roundabout square in Brussels, in front of the EU headquarters, 14 September 2015. (c) John Thys / AFP / Ritzau Scanpix.

\section{Contesting the universal status of 'Kurdi'}

The discursive constitution of Alan Kurdi as an innocent victim worthy of grief, sympathy, and compassion is remarkably widespread and consistent across the world. There was also a widely shared consensus on attributing responsibility for 'Kurdi's' death to political actors, rather than to Kurdi's family. However, two discourses challenge this dominant narrative about Kurdi's death. The first discourse questions the authenticity of the photographs, suggesting that the body had been moved and arranged on the beach as part of a political plot to garner global compassion; that Alan Kurdi had not drowned, but was killed to set up a fake scene. ${ }^{75}$ The history of photojournalism, including war photography, is filled with examples of shots that are staged in particular ways, for example, by moving objects in or out of the frame. The charge that the photograph of 'Kurdi' was inauthentic could draw support from this tradition at a general epistemological level. Interestingly, those charges are expressed on social media such as Twitter and Facebook and anti-establishment websites and blogs by conspiracy bloggers, but they go virtually unmentioned in traditional news media. ${ }^{76}$ The second discourse revolves around Abdullah Kurdi, the father of Alan. Some implied that he was opportunistic; that the

\footnotetext{
${ }^{75}$ Rowena Mason, 'Farage attacks “soft Eurosceptics” over EU exit campaign', The Guardian (25 September 2015), available at: $\{$ https://www.theguardian.com/politics/2015/sep/25/farage-sideline-eu-exit-campaign-ukip-eurosceptics-cameron-europe $\}$ accessed 18 December 2018.

${ }^{76}$ Lizzie Dierden, 'The fake refugee images that are being used to distort public opinion on asylum seekers', The Independent (16 September 2015), available at: \{https://www.independent.co.uk/news/world/europe/the-fake-refugeeimages-that-are-being-used-to-distort-public-opinion-on-asylum-seekers-10503703.html\} accessed 18 December 2018.
} 
family was in no danger in Turkey and that he was to blame for Alan's death. ${ }^{77}$ A story also appeared that Abdullah Kurdi was a people-smuggler and personally responsible for the boat tipping over and killing his wife and two sons. ${ }^{78}$ The accusations against Abdullah Kurdi for putting his child in such a dangerous situation do not, however, question the constitution of Alan Kurdi as worthy of grief, sympathy, and compassion.

The status of 'Kurdi' as worthy of grief, sympathy, and compassion is also evidenced by the absence of humorous, ironic, or satirical Internet memes and the uproar caused by a satirical cartoon in Charlie Hebdo in January 2016, in response to incidents in Cologne on New Year's Eve. In this drawing, two men are chasing women, with the text saying 'What would the little Aylan have grown up to be? A groper in Germany ${ }^{79}$ - and in the corner a small drawing of a body on the shoreline, to remind readers of the original image of Kurdi. As Mette Mortensen points out, this cartoon 'can be seen as an iconoclastic attempt to contest the emotionality awakened by the photographs of Alan Kurdi'. ${ }^{80}$ The cartoon generated widespread media and social media critique for being unethical and possibly racist. ${ }^{81}$ At a more general level, the cartoon was a challenge to the modern Western constitution of the subjectivity of the child as inherently innocent and in need of protection. This innocence is lost, however, as the child matures. ${ }^{82}$ Suggesting that Alan Kurdi might grow up thus challenges the constitution of 'Kurdi'/the child as a universal subject of grief. $^{83}$

\section{'As a father': Political subjectivity and emotion}

The immediate and widespread constitution of 'Kurdi' as a moving image calling for political action put pressure on those with the capacity to adopt policies on refugees and migration in and around the Mediterranean Sea. Emotional-discursive responses to images are, according to our theoretical framework, performative in two respects: images are constituted as communicating in a particular manner and those who see them are constituted with a particular subjectivity. This section provides a brief analysis of how politicians in Western Europe and North America constituted themselves through their responses to 'Kurdi'.

The first thing to notice is that the discursive constitution of emotionality is so dominant that it becomes a central reference. President Francois Hollande, for example, states that 'The photograph of the child on the beach brings a lot of emotion. ${ }^{84}$ Other leaders such as David Cameron,

\footnotetext{
${ }^{77}$ Claire Phipps, 'Refugee crisis briefing: Clashes in Lesbos, “open arms” in Brazil and dozens march to Sweden', The Guardian (8 September 2015), available at: \{https://www.theguardian.com/world/2015/sep/08/refugee-crisis-briefingclashes-lesbos-open-arms-brazil-march-sweden\} accessed 18 December 2018.

${ }^{78}$ Michael Powell and Zia Weise, 'Aylan and his father: their REAL story', Mail on Sunday (13 September 2015), available at: $\{$ https://www.pressreader.com/uk/the-scottish-mail-on-sunday/20150913/281960311534839\} accessed 18 December 2018. The trial in Bodrum decided to drop these charges against Abdullah Kurdi in March 2016. Mail Foreign Service, 'Court clears Aylan's father', Daily Mail (12 February 2016).

${ }^{79}$ Tim Hume, 'Outrage over Charlie Hebdo cartoon of dead toddler Alan Kurdi as sex attacker', CNN (14 January 2016), available at: $\{$ http://edition.cnn.com/2016/01/14/europe/france-charlie-hebdo-aylan-kurdi/\} accessed 20 December 2018.

${ }^{80}$ Mortensen, 'Constructing, confirming, and contesting icons', p. 1157.

${ }^{81}$ Adam Boult, 'Charlie Hebdo criticised over "racist” cartoon portraying Aylan Kurdi as an adult sex pest', The Telegraph (13 January 2016), available at: \{http://www.telegraph.co.uk/news/worldnews/europe/france/12098437/Charlie-Hebdo-criticised-over-racist-cartoon-portraying-Aylan-Kurdi-as-an-adult-sex-pest.html\}; Aziz Allilou, 'Charlie Hebdo mocks the death of Syrian child Aylan Kurdi', Morocco World News (13 September 2015), available at: \{http://www.moroccoworldnews. com/2015/09/167835/charlie-hebdo-mocks-the-death-of-syrian-child-aylan-kurdi/\} accessed 18 December 2018.

${ }^{82}$ Burman, 'Innocents abroad', p. 239.

${ }^{83}$ The appropriation of 'Kurdi' by Chinese artist Ai Weiwei in January 2016 was also criticised for turning the attention away from Alan Kurdi and towards the artist. Mortensen, 'Constructing, confirming, and contesting icons', p. 1155.

${ }^{84}$ Daily Sabah with Agencies, 'French president calls Erdoğan over images of drowned Syrian boy, calls for common EU refugee policy', Daily Sabah (3 September 2015), available at: $\{$ http://www.dailysabah.com/diplomacy/2015/09/03/frenchpresident-calls-erdogan-over-images-of-drowned-syrian-boy-calls-for-common-eu-refugee-policy\} accessed 19 December 2018.
} 
quoted above, are equally emotional in their immediate reactions. As in the general response to 'Kurdi', an emotional bundling takes place as a range of responses are recorded. 'Pain' and 'grief are mentioned, for example, by Swedish Prime Minister Stefan Löfven. ${ }^{85}$ 'Shame' and 'sympathy' are used by politicians not in office, criticising those who are, for their inaction. ${ }^{86}$

That 'Kurdi' shows the need for doing something is stressed, for example, by Enda Kenny, the Prime Minister of Ireland, who states that 'I think that picture more than any I've seen may shock political processes into taking action, both in terms of the stream of migrants and the causes that underlie that. ${ }^{, 87}$ Or as Hollande puts it, 'If the picture went viral around the world, it must also get a round of responsibilities. ${ }^{, 88}$ The need to act and the urgency of the situation is stressed through claims to other victims, including those of the future. In the words of Hollande, 'I think about all the victims that are never photographed, and the future victims if we do nothing.' As Erica Burman points out, the child has a particular capacity to symbolise the future. ${ }^{89}$ What is at stake is thus not only other children in danger of drowning as they venture across the Mediterranean Sea, but future itself.

Politicians speak of 'shock' and emotion. The epistemic significance of 'Kurdi' is not derived from its ability to document the refugee crisis, but from making the ramifications of the crisis felt at a human, personal, and visceral level. This enables the articulation of political subjectivities beyond formal positions of power and authority. As politicians stress their emotional responses they constitute themselves as experiencing feelings that are shared by all humans. They become embodied, human individuals rather than, or in addition to, their political positions.

There is, in addition to the general constitution of a shared human subjectivity, a recurring articulation of the subject position of being a parent, and more specifically a father. Enda Kenny argues that 'Any parent could see that child in their own arms', 90 and then-UK Liberal Democrats leader Tim Farron said 'it was appallingly hard to look at as a father'. ${ }^{91}$ The constitution of those who speak as 'parents' and 'fathers' deepen and further embody the creation of a commonality between politicians and other parents and fathers. The subject positions of 'parents' and 'fathers' involve a differentiation to those who do not have children. It is also a hierarchical differentiation: those with children have the capacity to feel in a stronger way than those who do not. But this differentiation coexists with a universality insofar as 'the parent' is situated in reference to 'the child'. 'The child' is, as noted above, a universal signifier of innocence and vulnerability, not just for those who have (small) children, but for everybody. ${ }^{92}$ The articulations of feeling like a parent or a father might thus also be an invitation for everyone to appropriate and feel like those subject positions.

The particular subject position of being a father has obvious gendered connotations. As feminist work has highlighted, the constitution of men as rational and women as emotional has a long history, yet the gendering of the reason-emotion dichotomy is performed rather than given and it is performed with specificity and nuance across time and place. ${ }^{93}$ There are

\footnotetext{
${ }^{85}$ Niklas Svensson, 'Stefan Löfven om bilden på Aylan, 3', Expressen (3 September 2015), available at: \{http://www.expressen.se/nyheter/stefan-lofven-om-bilden-pa-aylan-3/\} accessed 19 December 2018; House of Commons, Hansard 599 (9 September 2015); Canadian House of Commons, $42^{\text {nd }}$ Parliament, $1^{\text {st }}$ session (12 April 2016).

${ }^{86}$ House of Commons, Hansard 599.

${ }^{87}$ Lise Hand, “A young boy ... washed up on beach like driftwood” - Taoiseach describes migrant crisis as "human catastrophe”, Independent.ie (3 September 2015), available at: $\{$ http://www.independent.ie/irish-news/a-young-boy-washed-upon-beach-like-driftwood-taoiseach-describes-migrant-crisis-as-human-catastrophe-31500065.html\} accessed 19 December 2018.

${ }^{88}$ Daily Sabah with Agencies, 'French President calls Erdoğan over images of drowned Syrian boy'.

${ }^{89}$ Burman, 'Innocents abroad', p. 240.

${ }^{90}$ Hand, "“A young boy ... washed up on beach like driftwood"'.

${ }^{91}$ House of Commons, Hansard 599.

${ }^{92}$ Burman, 'Innocents abroad'.

${ }^{93}$ Jean Bethke Elshtain, Women and War (Chicago: University of Chicago Press, 1987); J. Ann Tickner, Gendering World Politics: Issues and Approaches in the post-Cold War Era (New York: Columbia University Press, 2001).
} 
hegemonic masculinities (and femininities) that define 'the currently most honored way of being a man' (and a woman) but these are performed through practice, including discursive practice. ${ }^{94}$ They are social, in short, rather than biological. The performance of an emotional masculinity in the response to 'Kurdi' questions a rigid constitution of men as incapable of feeling or unable to admit to being emotionally touched. Emotional masculinity is, however, performed in a way that is relatively controlled. Male politicians speak about their emotional responses, but they are capable of speaking and do not burst into tears, for example. As Claire Duncanson has shown, hyper-emotional outbursts can be constituted as feminising men who perform them. ${ }^{95}$ Hyper-emotional men are then typically situated in an inferior position compared to men who can feel while mastering their feelings. The ability to act is one of the most significant signifiers for the subjectivity of being a politician. In the specific context of politicians' masculinity, it is important, therefore, that the performance of emotions does not compromise the constitution of the subject as capable of acting. 'Normal' human beings may be overwhelmed by emotions, but politicians must have the capacity to respond for the common good.

The subjectivities of father and parent are connected to demands for political action in the discursive response to 'Kurdi'. To invoke 'fathers' and 'parents' might strengthen the urgency of the issue by locating it within the realm of a shared human and emotionally felt responsibility. But it is worth noting that the subjectivities of 'fathers' and 'parents' might also work to depoliticise an issue if articulated such that politicians are responding in a private, personal capacity. In short, 'as a father' does not by itself ensure that collective policies are pursued.

Interestingly, we only found one, relatively marginal, articulation of the subject position of being a mother. On Facebook and Twitter, posts praising Angela Merkel with words such as 'Mama Merkel, mother of the outcasts' appeared in September 2015. Moreover, Syrians were sharing images of the German chancellor with grateful slogans such as 'Wir lieben dich' ('We love you') or 'Compassionate mother'. ${ }^{96}$ Apart from this constitution of a compassionate Merkel (not articulated by Merkel herself), we find a striking absence of mothers. We have looked at a very large material covering the US, Canada, the UK, Germany, France, and the EU and there are plenty of female leaders who speak. Not all of these are mothers to children, Angela Merkel is not, for example, but many are, including Federica Mogherini, then-EU High Representative. ${ }^{97}$ One possible interpretation of the absence of 'mothers' is that an emotional response is already implied in the subject position of being a woman. To explicitly articulate an emotional response might thus risk 'hyper-emotionalizing' a female politician's subject position, raising questions about her capacity to act.

\section{The political impact of 'Kurdi'}

In this last part of the analysis, we ask: what was the impact of 'Kurdi' on refugee and migration policies? The question may seem straightforward, but the answer is not, as we will show in this section. Our theorisation of policy discourses and images laid out above enables us to capture the complex and performative ways in which 'Kurdi' was connected to policy.

We start from what has become an established narrative of how 'Kurdi' changed public attitudes and policies across Europe. ${ }^{98}$ It is worth noting that this narrative takes hold from very early

\footnotetext{
${ }^{94}$ R. W. Connell and James W. Messerschmidt, 'Hegemonic masculinity: Rethinking the concept', Gender \& Society, 19:6 (2005), p. 832; Lauren Wilcox, 'Practising gender, queering theory', Review of International Studies, 43:5 (2017), pp. 789-808.

${ }^{95}$ Claire Duncanson, 'Forces for good? Narratives of military masculinity in peacekeeping operations', International Feminist Journal of Politics, 11:1 (2009), pp. 63-80.

${ }^{96}$ Philip Oltermann, 'Mama Merkel: the compassionate "mother” of Syrian refugees', The Guardian, available at: \{https:// www.theguardian.com/world/shortcuts/2015/sep/01/mama-merkel-the-compassionate-mother-of-syrian-refugees? CMP=share_btn_tw\} accessed 19 December 2018.

${ }^{97}$ Federica Mogherini, official website, available at: \{http://www.federicamogherini.net/?lang=en\} accessed 1 July 2019.

${ }^{98}$ Bleiker, Visual Global Politics, p. 19.
} 
on. Indeed, the instant iconic status of 'Kurdi' is strengthened by the claim that the photographs changed European refugee and migration policy. Politicians in Canada, France, Germany, the UK, the US, and the European Parliament all refer to the publication of the images of Kurdi as a defining political moment, thereby establishing a clear before and after 'Kurdi'. 99 The same claim is found across media. ${ }^{100}$ These accounts of the images having impact are not descriptive, but performative, and help to constitute the iconicity of the photographs. In fact, 'Kurdi' is articulated as having had impact only a few days after the incident, at a moment where the actual political consequences that can be attributed to the images' circulation are almost impossible to assess. Explaining the inclusion of 'Kurdi' on their list of the 100 'Most Influential Images of All Times' in 2016, Time Magazine held that because of its wide circulation, 'European governments were suddenly compelled to open closed frontiers. Within a week, trainloads of Syrians were arriving in Germany to cheers, as a war lamented but not felt suddenly brimmed with emotions unlocked by a picture of one small, still form. ${ }^{101}$ In short, the narrative about the political impact of the photographs of Kurdi had an important performative role in producing and reproducing the photographs' status.

At first sight, EU refugee policy appeared to change after images of 'Kurdi' went viral on 2 September 2015. On 3 September, French President Hollande called for a fair and humane policy on immigration, suggesting that a joint French-German initiative could help solve the refugee crisis. ${ }^{102}$ The French-German initiative launched by Hollande proposed a permanent and mandatory mechanism for the distribution of refugees. ${ }^{103}$ This initiative came on the backdrop of a spring and summer demonstrating deep divisions between European countries on how to tackle the refugee crisis. Numerous EU meetings on relocations of asylum seekers from Italy and Greece to other member states had failed to lead to an agreement. The French-German initiative was a noteworthy policy change as a previous proposal on mandatory refugee quotas put forth by the EU Commission had been rejected by Paris and Berlin in June. Angela Merkel stated that the new French-German position represented a 'sharing of duty ... the principle of solidarity'. ${ }^{104}$ It echoed Merkel's decision to suspend the Dublin agreement and welcome all Syrians, irrespective of where they had set foot before. A decision defended in Merkel's famous statement a few days before the death of Alan Kurdi that 'Wir haben so vieles geschafft - wir schaffen das'. The German 'we' that 'could do this' invoked by Merkel was now sought extended to that of Europe.

A striking articulation of a shared European responsibility took place on 14 September 2015 in conjunction with a visit to Brussels by Tima Kurdi, the aunt of Alan Kurdi. Invited by the organisation Avaaz, she spoke in front of the Welcome Wall featuring the remediation of 'Kurdi' as an angel. In her emotionally laden speech, Tima Kurdi told reporters that Europe should not close the door on desperate refugees (Figure 3). ${ }^{105}$ She met with the media and held private meetings with Donald Tusk, President of the Council of the European Union, Members of the European Parliament and then-EU High Representative Federica Mogherini. At their meeting, Mogherini

\footnotetext{
${ }^{99}$ House of Commons, Hansard 599 (8 September 2015); see also Hansard 599 (9 September 2015).

${ }^{100}$ Mary Jo Leddy, 'Refugee issue now defines federal race', The Toronto Star (16 September 2015).

101'100 photos: Alan Kurdi', Time Magazine (2016), available at: \{http://100photos.time.com/photos/nilufer-demir-alankurdi\} accessed 2 January 2017. See also Bleiker, Visual Global Politics, p. 19.

${ }^{102}$ Daily Sabah with agencies, 'French President calls Erdoğan over images of drowned Syrian boy'.

${ }^{103}$ Bundesregierung, 'Resolving the refugee problem at European level', The Press and Information Office of the Federal Government (4 September 2015), available at: \{https://www.bundesregierung.de/Content/EN/Artikel/2015/09_en/2015-0904-fluechtlinge-gesamt_en.html\} accessed 20 December 2018.

${ }^{104}$ Kim Willsher, 'Germany and France demand binding refugee quotas for EU members', The Guardian (3 September 2015), available at: \{https://www.theguardian.com/world/2015/sep/03/germany-france-eu-refugee-quotas-migration-crisis\} accessed 20 December 2018.

${ }^{105}$ The Canadian Press, 'Tima Kurdi travels to Brussels to call for more help for Syrian refugees', The Hamilton Spectator (14 September 2015), available at: \{http://www.thespec.com/news-story/5842302-tima-kurdi-travels-to-brussels-to-call-formore-help-for-syrian-refugees/\} accessed 20 December 2018.
} 


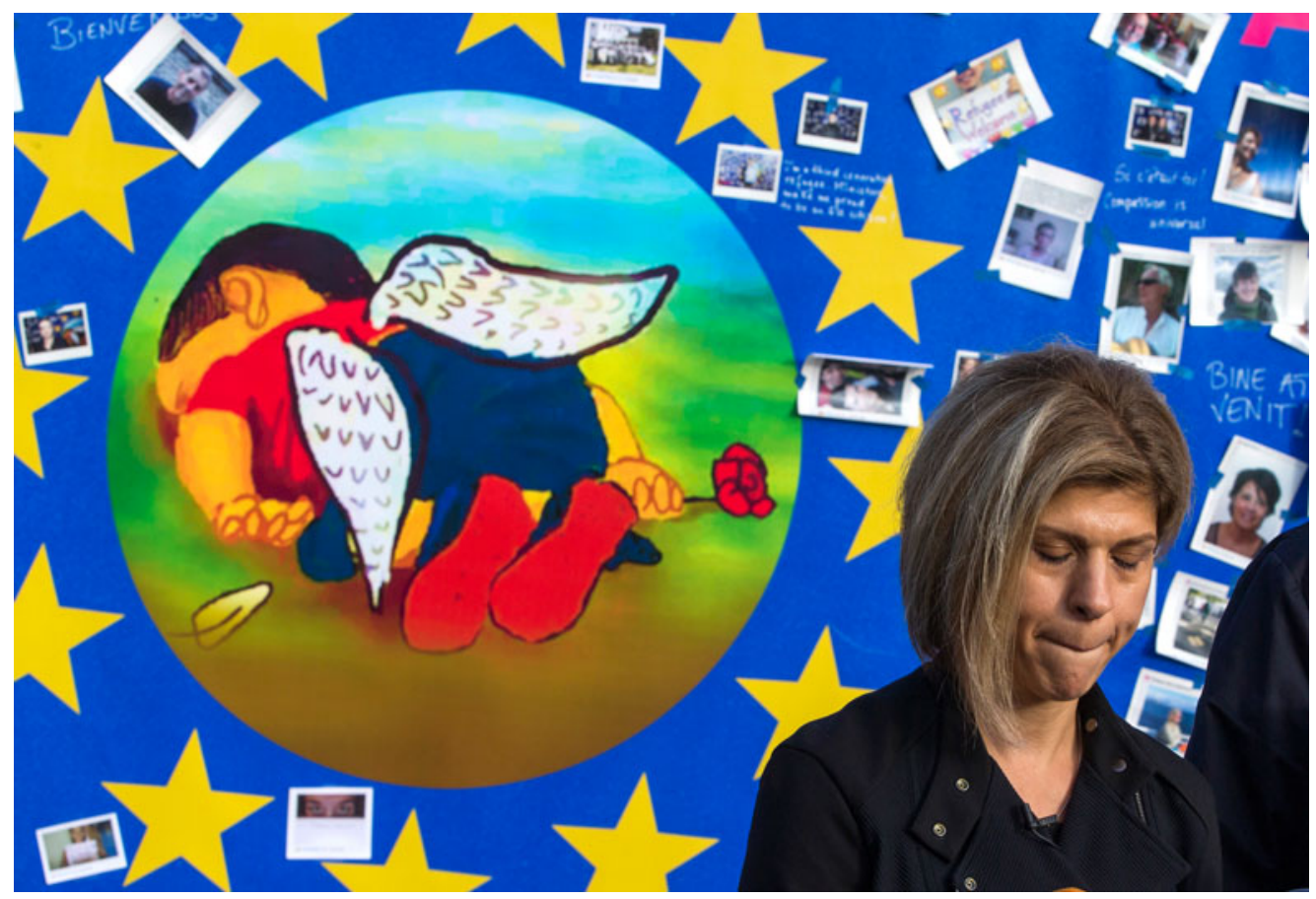

Figure 3. Tima Kurdi in front of the Welcome Wall, Brussels, 14 September 2015. ( Yves Herman / Reuters / Ritzau Scanpix.

articulated a sense of shame and assumed a responsibility, which could be interpreted both as personal and political. Mogherini said:

Some of you said today it's the pictures that are changing the mood and one picture in particular. All pictures of women and children we never see still exist ... Surely together we can do more. We have to reflect on our mistakes. ${ }^{106}$

Inside the Council building in Brussels, a few hundred metres away, the EU interior ministers held an emergency meeting and agreed to share the 40,000 migrants sheltering in Greece and Italy, but only on a voluntary basis. Several East and Central European countries remained resolute in their opposition to the compulsory distribution. On 22 September, EU interior ministers met again to discuss relocation of migrants and refugees. Here, they finally approved a controversial plan to relocate 120,000 migrants across the continent over two years. The EU Presidency and a number of states pushed towards the vote. Romania, the Czech Republic, Slovakia and Hungary voted against accepting mandatory quotas. In October 2015, the EU relocation scheme began at a very slow pace with the plan to relocate asylum seekers from Greece and Italy to other European countries.

Taking a broader view of the policy discourse in September 2015, there are politicians that very explicitly connect 'Kurdi' to the need for a particular policy. An example is Member of the European Parliament Cecilia Wikström who held that Alan Kurdi lost his life but he brought passion - and compassion - back to the European debate on migration and therefore we will remember him for a very long time. ... We must review the existing asylum legislation in Europe and adapt it to this

\footnotetext{
${ }^{106}$ Sheldon Chad, 'Aunt of drowned Syrian boy urges Europe to act now before more children die', The Globe and Mail (15 September, 2015), available at: \{http://www.theglobeandmail.com/news/world/tima-kurdi-calls-on-europe-to-act-nowbefore-more-migrant-children-die/article26375621/\} accessed 20 December 2018.
} 
century to provide for legal and safe routes to get here. We must agree to a system of binding quotas of refugees to be accepted by every Member State .... ${ }^{107}$ Many other statements constituted 'Kurdi' as calling for an urgent response, while remaining vague as to which policy should be adopted. ${ }^{108}$

Assessing the impact of 'Kurdi' on European policies on migration and refugees is complicated, not only because of the loose coupling of 'Kurdi' and a specific policy in much of the discourse, but because the negotiations over a joint relocation mechanism within the EU took place at the same time as hundreds of thousands of migrants and refugees were on the move up through Europe. ${ }^{109}$ While the wrangling over the distribution of asylum seekers played out in Brussels with 'Kurdi' as continuous reference, Austria, Slovakia, and the Netherlands introduced border controls following Germany's decision on 13 September to set up checks on its own southwestern frontier, as refugees came in great numbers following Angela Merkel's suspension of the Dublin system. On 15 September, Germany and France called for tighter controls of Europe's external borders. ${ }^{110}$ The German government explained that controls along the German-Austrian border were only a temporary emergency measure, but the restrictions signalled that Merkel's welcoming stance towards refugees and migrants was encountering domestic resistance. Sweden, another staunch supporter of an open-door policy, introduced border controls on 12 November. The 26 Schengen member states had previously periodically reinstated border checks, but never because of pressures from migration. Visually, there were plenty of images of refugees trying to board overfilled trains and filling the streets that acted as 'counterimages' to 'Kurdi'. Children featured in those images too, but no single photograph gained an iconic status similar to 'Kurdi'. 'Kurdi' does not feature explicitly in the justifications for closing state borders, which is perhaps not too surprising considering the consistent discursive and nondiscursive practices that had made the image an iconic symbol of a subject in need of care.

This, however, changes in 2016, as 'Kurdi' is actively mobilised in support of the controversial agreement between the EU and Turkey. On 8 March 2016, at the initiative of Merkel, the EU concluded the agreement, involving an initial three billion euros payment and opening new chapters in Turkey's full membership bid and visa-free travel for Turkish citizens, in exchange for Turkey receiving migrants trying to reach Europe via the Aegean Sea. Germany had been warming up for this for months, despite criticism from both NATO and EU allies for acting unilaterally and ignoring human rights breaches in Turkey. ${ }^{111}$ Per the agreement, the EU would take a Syrian refugee from Turkey in exchange for every Syrian returned to Turkey from Greek islands. From the very beginning, Amnesty International and other human rights bodies criticised the deal. ${ }^{112}$ Turkey had not signed up in full to the UN Refugee Convention and it had, in violation of international law, sent Syrians back to Syria. On 23 April 2016, Turkish Prime Minister Davutoğlu spoke at a joint news conference with Merkel to promote the controversial deal. Davutoğlu said that the number of migrants crossing illegally into Greece had dropped from

\footnotetext{
${ }^{107}$ European Parliament, Debates (9 September 2015), available at: $\{$ http://www.europarl.europa.eu/doceo/document/CRE8-2015-09-09-ITM-006_EN.html?redirect\} accessed 20 December 2018.

${ }^{108}$ The emotional bundling through which the response to 'Kurdi' was constituted might have played a role in making such weak links possible. It would, however, require a longer analysis of European refugee and migration policy to determine all the factors - including emotional bundling - that might explain the policy decisions that were taken.

${ }^{109}$ Virginie Guiraudon, 'The 2015 refugee crisis was not a turning point: Explaining policy inertia in EU border control', European Political Science, 17:2 (2017), p. 157.

${ }^{110}$ Kiersten Nelson, 'The European Crisis: “There Cannot Be Humanity Without Firmness and Responsibility", Kennedy Center of International Studies (15 September 2015), available at: $\{$ https://kennedylive.wordpress.com/2015/09/15/the-european-crisis-there-cannot-be-humanity-without-firmness-and-responsibility/\} accessed 20 December 2018.

${ }^{111}$ Jennifer Rankin, 'Turkey and EU agree outline of "one in, one out" deal over Syria refugee crisis', The Guardian (8 March 2016), available at: \{https:/www.theguardian.com/world/2016/mar/08/european-leaders-agree-outlines-of-refugeedeal-with-turkey\} accessed 20 December 2018.

${ }^{112}$ Berza Simsek and Susan Fraser, 'Rights group: EU should "rethink” Turkey refugee deal', Business Insider (23 April 2016), available at: $\{$ https://www.businessinsider.com/ap-rights-group-eu-should-rethink-turkey-refugee-deal-2016-4?r=US\&IR=T\&IR=T $\}$ last accessed 18 December 2018.
} 
around 6,000 per day in November to around 130 daily since the beginning of April. He explained: 'Our priority was to stop the baby Aylans from washing up on the shores, and we have made great strides in this aim. ${ }^{113}$ 'Kurdi' had been institutionalised as an emotionally charged reference to be mobilised not only in defence of open-door policies, but also to prevent refugees from attempting to enter EU-Europe.

The articulation of 'Kurdi' as warranting a policy of preventing migrants and refugees from attempting to reach Greece is a striking illustration of the performative relationship that exists between images, emotions, and policies. Images do not cause specific policies to be adopted. Whether images can be mobilised in support of opposing policies is thus an empirical question. It is, furthermore, worth noting that the agreement between the EU and Turkey is presented by Davutoğlu as an act of care and protection in defence of vulnerable, innocent victims. This evokes a paternalistic discourse with a privileged position for the speaking and acting subject who cares and knows better than actual parents which decisions to make when confronted with such difficult choices as Alan Kurdi's parents.

Our focus in this section has been on how 'Kurdi' impacted on policymaking and discourse within the EU. The relationship of 'Kurdi' to policymaking is more complicated - and thus theoretically interesting - within the EU than in North America. However, 'Kurdi' shaped refugee policy and debates in North America as well. At the level of domestic politics, in Canada the images were widely seen to have had crucial political impact on the 2015 federal election as it was reported just hours after the images went viral that Kurdi had a connection to Canada. Looking back, The Toronto Star concluded: 'his death caused recrimination so strong it helped elect an idealistic, refugee-friendly prime minister, Justin Trudeau'. ${ }^{114}$ Both in Canada and the US the immediate policy impact was the promise of accepting more refugees from the Syrian war. Just days after 'Kurdi', President Obama announced a plan to resettle 10,000 Syrian refugees over the next year, whereas Trudeau's new Liberal government, upon coming to power in Canada after the October election, started out by accepting 25,000 Syrian refugees - the first arrivals personally welcomed by Trudeau and his wife at the airport. ${ }^{115}$

Illustrating the performative relationship between images and policy, 'Kurdi' is linked more explicitly to Western interferences in the Syrian war in an American than in a European context. Many Republicans argued that the Syrian refugee crisis was a result of Obama's failed military policy, but also that children like Alan Kurdi were in need of help. Even immigration-critical Republicans such as New Jersey Governor Chris Christie said that: 'I'd sit down with our allies and figure out how we can help, because America is a compassionate country ... We saw the image of that 4-year-old [sic] little boy drowned in Syria, and we can't have those kinds of things. ${ }^{116}$ The terrorist attacks in Paris in November 2015 likewise had a bigger impact in North America than in Europe where discourses and policies had already emerged focused on protecting external and internal borders. Following the Paris attacks, Governor Christie stated that the US should not accept any new Syrian refugees, not even young orphans. On 19

\footnotetext{
${ }^{113}$ Berza Simsek, 'Turkey hails "effective” migrant deal as EU leaders visit', AP News (23 April 2016), available at: \{https:// apnews.com/3993402a62c742e492b1e3e9aa44c696\} accessed 20 December 2018.

${ }^{114}$ Jodi Kantor and Catrin Einhorn. 'Refugees encounter a foreign word: Welcome', The New York Times (3 July 2016), available at: \{https:/www.nytimes.com/2016/07/01/world/americas/canada-syrian-refugees.html $\}$ accessed 20 December 2018. Former Canadian immigration minister Chris Alexander thinks Russian Internet trolls weaponised Alan Kurdi's image against the Federal Conservatives in the 2015 election. See \{https://www.globalreport.ca/single-post/2019/07/27/ Trump-turmoil-social-media-How-Russia-is-disrupting-the-West\}. We thank Eric Van Rythoven for this point.

${ }^{115}$ Jessica Murphy, 'Trudeau greets Syrian refugees as Canada prepares for more arrivals', The Guardian (11 December 2015), available at: \{https://www.theguardian.com/world/2015/dec/11/canada-syrian-refugees-arrive-whitehorse-yukon\} accessed 20 December 2018.

${ }^{116}$ Gregory Krieg, 'Christie on refugees: Not even 5-year-old orphans', CNN (17 November 2015), available at: \{http://edition.cnn.com/2015/11/17/politics/chris-christie-paris-attacks-refugee-orphans/\} accessed 3 July 2019.
} 
November 2015, the US House passed a ban on Obama's plan to resettle 10,000 refugees. ${ }^{117}$ Trudeau set back his original plan to resettle 25,000 refugees by 31 December 2015 to instead settle 10,000 refugees by December, and then an additional 15,000 by March $2016 .{ }^{118}$ 'Kurdi', unsurprisingly, is not invoked when Trudeau justifies this decision. The absence of references to 'Kurdi' in the retightening of the US and Canadian refugee policies, should not, however, be taken to mean that Kurdi has disappeared. On the contrary, Kurdi remains an icon. To take an example: on the official webpage of the Government of Canada, a video is featured with an interview with Tima Kurdi saying 'the image of my nephew Alan, who woke up the world, and finally people in the world ... they start to realize, the suffering of refugees'. ${ }^{11}$

\section{Conclusion}

It is often claimed that images have the capacity to invoke emotions, and that emotions in turn are significant for how international politics is conducted. This article has presented a theoretical framework that enables analysis of how images, emotions, and foreign policies are constituted and connected through discourse. Our theoretical framework is thus a contribution to how IR scholars may study emotions as social, collective phenomena, rather than inner, psychological, or neurological states of being. Our framework is performative in several ways. It theorises how the meaning of images, what they 'say' and how one should feel about them is performed and constituted through discourse. Some motifs have a history of being able to invoke emotions and such traditions can be drawn on and reproduced in discourse; indeed, such reproductive statements are themselves performative. The relationship between images and emotions is performatively linked to foreign policies. Emotionally charged images are said to call for particular foreign policy responses, and particular foreign policy responses are said to be warranted by 'emotional images'. We introduced the concept of emotional bundling to capture how a range of diverse emotions might be brought together in discourse to constitute 'an' emotional response. Emotional bundling might increase the pressure on foreign policymakers, but it might also decrease the precision of what policy changes are being demanded. Our theoretical framework draws attention to how emotional discourse constitutes the meaning of images as well as the subjectivity of those who see and respond to them. The performative constitution of political subjectivity might humanise those with the capacity to adopt foreign policies. It might increase the demand for action, but it might also depoliticise if the emotional response is constituted as one of responding as a normal human being, rather than a political authority. Our framework enables analysis of how the policy implications of emotional images are constituted, how multiple policies can be said to derive from the same image, and how performative accounts of how an image changed policies can be significant for the iconicity of an image.

The second part of the article provided an analysis of the photographs of Alan Kurdi using our theoretical framework. Our analysis emphasised the strong and widely shared emotional response to 'Kurdi' and the emotional bundling that took place, and we critically engaged the accounts of 'Kurdi' as having had a profound impact on migration policies in Europe and North America. We argued that the historicity and iconography of 'the child' was significant for understanding the

\footnotetext{
${ }^{117}$ Ray Sanchez, 'After Paris attacks: France and U.S. struggle with Syrian refugee issue', CNN (19 November 2015), available at: \{http://edition.cnn.com/2015/11/19/world/paris-attacks-us-france-refugees/\} accessed 3 July 2019.

${ }^{118}$ The Canadian Press, 'Americans take notes on Canada's Syrian refugee response', The Huffington Post (7 November 2016), available at: \{http://www.huffingtonpost.ca/2016/07/11/washington-canada-syrian-refugees_n_10933532.html\} accessed 20 December 2018.

${ }^{119} \mathrm{See}\{\mathrm{http}: / / \mathrm{https}: / /$ www.canada.ca/en/immigration-refugees-citizenship/news/video/tima-kurdi-speaks-about-refugees. html accessed 5 July 2019. In June 2019, a photograph of a Salvadoran father and his 23-month-old daughter who drowned in the Rio Grande in their attempt to cross into Texas, was headlined across the world and the UN refugee agency made comparisons with the photographs of 'Kurdi'. See \{https://www.theguardian.com/us-news/2019/jun/25/photo-drownedmigrant-daughter-rio-grande-us-mexico-border?CMP=Share_iOSApp_Other\} accessed 12 August 2019.
} 
emotional response to 'Kurdi' and that the constitution by politicians as 'parents' and 'fathers' drew upon a gendered constitution of reason and emotion in complicated ways.

Taking a step back from our analysis, and seeing 'Kurdi' as a case study, it is worth noting that other cases might stress other parts of our theoretical framework. There might be less consensus on which emotional response is warranted and there might be 'emotional competition' as well as, or instead of, emotional bundling. Other cases might involve other subjectivities than 'the child' and 'parents' and 'fathers' and a more prominent articulation of negative feelings such as hate, anger, repulsion, and offence than we found in the case of 'Kurdi'. We also wish to acknowledge that there are questions of theoretical and political significance that we have not had the space to address. The most important of these is probably the role of social media, particular as it is implicated in global structures of power and inequality. ${ }^{120}$ Though we have touched upon the role of social media in the circulation and remediation of 'Kurdi', we have not provided a full theorisation of the way in which social media, images, emotions, and international politics come together. We hope that future studies will do so. There is also a range of ethical questions concerning visual representations, particularly of humans subjected to suffering and pain or in death, and how one shows and writes about these representations, in general and in academic work in particular, that we have been unable to address. ${ }^{121}$ Finally, we imagine that future studies might link visual and emotional studies to the study of diplomacy, particularly how 'image management' might be practiced and discussed away from the public stage. ${ }^{122}$

Acknowledgements. Earlier versions of this article have been presented at seminars in the Department of Political Science, University of Copenhagen, and the School of Global Studies, University of Gothenburg. We wish to thank those present on those occasions for their criticisms, questions, and suggestions. We are particularly grateful to the following for their detailed feedback on the manuscript: the two anonymous reviewers, the editors of Review of International Studies, Joakim Berndtsson, Dean Cooper-Cunningham, Jakob Dreyer, Kristin Anabel Eggeling, Simone Molin Friis, Megan MacKenzie, Viktor Emil Sand Madsen, Iver B. Neumann, Swati Parashar, Sanna Strand, Alexei Tsinovoi, Patrice Wangen, Michael C. Williams; and to Fanny Hye-Knudsen, Sari Saadi, and Johan Spanner for comments and research assistance. Research for this article was carried out as part of the projects on 'Bodies as Battleground: Gender Images and International Security' funded by the Independent Research Fund Denmark, grant number 7015-00093B; 'DIPLOFACE' funded by the European Research Council Starting Grant, grant number 680102; and 'Images and International Security', funded by the Independent Research Fund Denmark, grant number DFF-1327-00056B.

Rebecca Adler-Nissen is Professor in the Department of Political Science, University of Copenhagen. She is author of Opting Out of the European Union: Diplomacy, Sovereignty and European Integration (Cambridge University Press, 2014) and editor of Bourdieu in International Relations: Rethinking Key Concepts in IR (Routledge, 2012). Her current research focuses on international political sociology, practice theory and practice methodologies, diplomacy, and the use of social media and digital technologies in international relations. Email: ran@ifs.ku.dk.

Katrine Emilie Andersen is Special Advisor on European policy and development at the Ministry of Foreign Affairs of Denmark and a former employee at the research project 'Images and International Security' at the University of Copenhagen. Before entering into political science, she worked in photojournalism. Email: katand@um.dk

Lene Hansen is Professor in the Department of Political Science, University of Copenhagen. She is author of Security as Practice: Discourse Analysis and the Bosnian War (Routledge, 2006) and co-author (with Barry Buzan) of The Evolution of International Security Studies (Cambridge University Press, 2009). Her main areas of current research are visual international politics, gender and security, critical security studies, discourse analysis and foreign policy, and critical methodologies and world politics. Email: lha@ifs.ku.dk.

\footnotetext{
${ }^{120}$ Berents, 'Hashtagging girldhood'.

${ }^{121}$ Elizabeth Dauphinee, 'The politics of the body in pain: Reading the ethics of imagery', Security Dialogue, 38:2 (2007), pp. 139-55.

${ }^{122}$ Rebecca Adler-Nissen and Alexei Tsinovoi, 'International misrecognition: the politics of humour and national identity in Israel's public diplomacy', European Journal of International Relations, 25:1 (2019), pp. 3-29.
}

Cite this article: Adler-Nissen, R., Andersen, K. E., Hansen, L. 2020. Images, emotions, and international politics: the death of Alan Kurdi. Review of International Studies 46, 75-95. https://doi.org/10.1017/S0260210519000317 